\title{
ІСТОРІЯ ЖІНОЧОЇ ЗЛОЧИННОСТІ
}

\begin{abstract}
Анотація. Стаття присвячена дослідженню істоpiї жіночої злочинності. Вказується, що спочатку жінка розглядалася виключно як об'єкт злочину. Доведено, що отримання жінками прав і свобод вплинуло на жіночу злочинність у цілому. Вказується, що жіноча злочинність має глибокі історичні корені, на іiї розвиток і тенденції впливали насамперед підвалини в суспільстві і релігія. Вивчення жіночої злочинності і боротьба 3 нею неможливі без дослідження історичної генези жіночої злочинності. Адже у разі прийняття та введення нових методик боротьби з жіночою злочинністю необхідно враховувати походження жінки та їі статус е суспільстві.
\end{abstract}

Ключові слова: історичний розвиток, причини злочинності, жіноча злочинність.

Постановка проблеми. 3 давніх часів жінка розцінювалася як слабка стать, перед нею встановлювалося безліч заборон і правил, яких вона зобов'язана була дотримуватися. Соціального статусу в суспільстві вона не мала, в ії обов'язки входило заняття господарством і виховання дітей. Наприклад, у Китаї жінка не мала права їсти разом з чоловіками, а в Бірмі - входити в деякі храми і в місця судилищ. У стародавніх іудеїв жінці під страхом смертної кари заборонялося одягати чоловічий одяг. У Стародавньому Римі вживання жінкою вина каралося стратою, таке ж покарання було передбачено для жінок тубільців Парагваю і готтентотів за пияцтво і надмірну обжерливість. У племені фанті (в Африці) жінці, яка підслуховувала таємниці свого чоловіка, обрізали вуха, а за розголошення їх - губи $[1$, c. 59]. Щоб зрозуміти причини жіночої злочинності, необхідно звернутися до історичного генезису розвитку злочинності в цілому, що і зумовлює актуальність обраної теми дослідження.

Указаним питанням тією чи іншою мірою приділяли увагу В. Внуков, М. Євдокімова, М. Сотрогорський, М. Пушкарьова, А. Яковлев та інші.

Метою статті є дослідження історії жіночої злочинності, зокрема їі причин.

Виклад основного матеріалу дослідження. У язичницькій Стародавній Русі не було будь-яких письмових джерел права, взаємини між слов'янами грунтувалися на язичницьких звичаях. Відомості про жінку-злочинця як суб'єкта злочину в язичницький період не збереглися. Становить складність уявити образ жінки-злочинця в язичницькому кримінальному праві. У зв'язку з тим, що до нас не дійшли відомості про кримінальну відповідальність чоловіків і жінок тієі епохи за скоєні ними злочини, вважаю, можна дійти висновку про те, що специфічних покарань для жінок не існувало.

Жінка як суб'єкт скоєного злочинного акту з'являється в джерелах не рідше, ніж як об'єкт злочину. Представниці всіх станів феодальної Русі, крім рабинь, були дієздатними особами, суб'єктами права, тому самостійно несли відповідальність за злочини. Відповідальність, зокрема матеріальну, за проступки, вчинені холопкою, ніс її володілець. Світське законодавство не зумовлювало розміри відповідальності за злочини саме жінок. Штрафи диференціювалися залежно не від статі, а від соціально-класової приналежності злочинця або злочинниці. Водночас церковні нормативи становлять велику групу проступків, за які жінка зобов'язана була нести покарання (незалежно від соціально-класової приналежності штрафи не диференційовані). Одним 3 них було перелюбство, за яке церква наказувала розлученням; крім того, чоловік мав право розлучення з дружиною з низки інших приводів, прирівнюваних до подружньої зради.

Крім перелюбу, вчиненого як заміжніми, так і незаміжніми «дружинами», широко побутували й інші проступки морально-етичного порядку. Шкала покарань за них була широка: від десятка покаянних поклонів (або декількох гривень штрафу) до декількох років посту. Особливо суворо каралися жінки, які вчинили дитяче «душогубство», «спотворили» в собі дитину, використавши для цього різні «зілля». Подібних «дружин» церква дозволяла чоловікам самим «стратити», тобто покарати.

Оскільки жінки на Русі нерідко брали участь і в різних бійках, Статут князя Ярослава не тільки виділив в окрему статтю «жіночу бійку», але і ввів спеціальні покарання за побої, нанесені власному чоловіку, а також іншій жінці. В останньому разі штраф був удвічі більший: 3 гривні за побої, нанесені чоловіку, проти 6 гривень за побиття жінки жінкою.

За крадіжки як один з видів кримінальних злочинів стягувалися рівні штрафи і $з$ чоловіків, і 3 жінок («тако ж і дружина», додає укладач Статуту Ярослава під час опису крадіжок конопель, льону, полотна). Крадіжка дружиною у власного чоловіка як проступок швидше морального, ніж кримінального порядку, що не тягла за собою покарання, але за підпал будинку на жінку накладався штраф. Примітно, що ситуація, коли чоловік продавав або пропивав жінчине добро, давала право жінці на розлучення [2, с. 139].

У Статуті князя Володимира «Про суд церковний і про десятину» згадується жіноча злочинність, така як перелюб, проституція, непослух. У Руській правді життя жінки і чоловіка захищалися неоднаково. Жінка споконвіку завжди була наділена не тільки фізіологічними особливостями, а й соціальним статусом у суспільстві. Ставлення до жінок завжди було двоїсте. По-перше, жінка, мудра і божественно красива, є продовжувачем людського роду. По-друге, в ній живе «грішниця», яка може зруйнувати чоловічу душевну рівновагу, його психічний стан, у своїх вчинках вона рішуча і корислива. Для будь-якого суспільного устрою, будь-якої історичної епохи характерно, що чоловік має більші права і свободу. Наприклад, на думку Аристотеля, чоловік і жінка - не рівні істоти. Жінка дає дитині тіло, чоловік - душу, душа краща і божественніша тіла. Чоловік норма, жінка - відхилення від неї. Чоловік вищий, жінка нижча за своєю природою. Чоловік панує, жінка підкоряється. 
У середні віки в Європі про жінку сформувалася думка, що вона $є$ спокусою, прирівнювалася до зла, вона по суті нижче, ніж чоловік. Зазначена позиція виходила від церкви і вищого духовенства. Разом $з$ тим класова належність грала чималу роль. Великими правами володіла жінка благородного походження, на відміну від простолюдинки і кріпаків. Більшість чоловіків середньовічної Європи все-таки вважали жінок другосортними істотами і вчиняли щодо них насильство.

У кримінальному праві середньовічної Європи зберігаються основи кровної помсти. Так, наприклад, у Салічній правді франків містяться норми, що стосуються кримінальної відповідальності за скоєння злочинів. За велику кількість злочинів передбачені були високі штрафи на користь потерпілого, частина від зазначеного штрафу перераховувалася на користь держави. У разі несплати штрафу злочинець був страчений або допускалася кровна помста щодо нього. В основному штрафи були високі, за несплату штрафу обов'язок щодо виплати поширювався на родичів правопорушника.

Родичі злочинця за Салічною правдою могли звільнитися від зазначених зобов'язань, звільнившись від родинних зв'язків шляхом проведення різних обрядів на судових зборах у присутності посадової особи - тунгіна.

У нормативно-правовому акті середньовічної Європи простежується принцип класового розшарування суспільства, виходячи iз соціального становища злочинця і потерпілого. Жінка середньовічної Європи уявлялася як продовжувачка роду, в зв'язку 3 цим скоєння злочину щодо жінки каралося значними штрафними санкціями. Потрійний вергельд (штраф на користь родичів потерпілого-убитого) сплачувався за вбивство жінки, в чотириразовому - за позбавлення життя вагітної жінки.

У Салічній правді також є статті, які містять покарання за образу жінки, за вчинення вказаного проступку штраф був вищий, ніж за образу чоловіка. Разом з тим розмежування покарання для жінок і чоловіків за Салічною правдою не проводилося.

Відомо, що в середні віки чаклунство вважалося злочином, що вчинявся в основному жінками. Як зазначено раніше, в християнстві панували чоловіки, жінки займали найнижче становище, вважалися слабкими, невірними, ласими, легко могли бути піддані впливу Диявола. Боротьба зі злочинністю жінок такого роду породила і відповідне «керівництво»: ним послужив «Молот відьом» Я. Шпренгера і Г. Інстіторіса, опублікований в 1486 році. Перераховуючи головні ознаки відьом (найбільш небезпечних, на думку авторів, злочинниць), вони вказують насамперед на приналежність особи до жіночої статі. Причетність чоловіків до відьомства заперечується, бо сам Христос був чоловіком. Як справедливо зазначив А.М. Яковлєв, «Молот відьом» являє собою один зі зразків релігійно-наукової теорії переваги чоловіків, виправдовуючи, навіть вимагаючи, переслідування жінок як представників нижчого, гріховного і небезпечного класу індивідів» [3, с. 124].

У «Кримінально-судовому укладенні імператора Карла V》 (далі - Кароліна) відзначено, що підозрою в чаклунстві і знахарстві були анонімні підозри родичів, знайомих, сусідів. Суди мали перевірити обгрунтованість обвинувачення в чаклунстві, часто досить було чуток, у суди також запрошували свідків.

У разі проведення відьомського процесу часто використовувалися «тортури», випробування над підозрюваною «відьмою», тобто пошук прикмет, за якими було здійснено 6 розпізнання відьми. «Випробування водою» проводилося катом: жінку оголювали, кат їй зв'язував руки і ноги, іiі опускали у воду. В ті часи вода вважалася символом чистоти, i якщо вона брала жінку, вона не вважалася відьмою. А якщо жінка, опущена в воду, спливала на поверхню, найчастіше так і відбувалося, то визнавалася відьмою.

У середні віки за відмітини на тілі могли прийняти за відьму i спалити. Пошук на тілі жінки відмітин називався випробуванням «відьомської відмітини». Мисливці на відьом стверджували, що Диявол мітить своїх поплічників. Зазначені позначки і шукали судді. Бородавки, родимки, плями або ділянки знебарвленої шкіри вважалися мітками Диявола, особливо, якщо вони виділяли якусь рідину або кровоточили. Вважалося, що зазначені позначки Диявол завдає на тіло жінки в прихованих місцях, тому, щоб їх визначити, жінкам голили голову і їх оголювали.

Ще був один спосіб розпізнання відьом - «випробування плачем». Про зазначене випробування згадано в трактаті про демонологію - «Молоті відьом». Жінку, яку звинувачують у чаклунстві, катували тривалий час. Тоді вважалося, що відьми не вміють плакати, а якщо жінка і починала плакати, від смерті це іiі не рятувало. Адже інквізиція вважала, що сльози, пролиті під тортурами, не є щирими.

Під час вивчення норм Кароліни було відзначено, що окремою також є стаття, яка передбачала кримінальну відповідальність жінок за дітовбивство. Решта норм Кароліни поширювалися на злочинців незалежно від статі.

«Якщо хто-небудь шляхом чаклунства заподіє людям шкоду або збиток, то він має бути підданий смертній карі, і ця страта мала бути проведена шляхом спалення. Якщо ж хто-небудь займається чаклунством, але не заподіяв цим нікому шкоди, то він мав бути (відповідно до обставин справи) покараний інакше, причому судді мали скористатися обставиною справи і відповідно до порад правознавців піддати вигнанню 3 країни, виставленню біля ганебного стовпа, відрізанням вух, покаранням різками або іншому покаранню. Жінка, яка зловмисно, таємно і по своїй волі вб’є свою дитину, що вже отримала життя і сформувалися іiі органи, має бути живцем похована і пробита колом [4, с. 34].

Пильну увагу до жінки з боку суспільства, держави і церкви можна пояснити зростанням злочинності і криміногенності осіб жіночої статі. Прикладом здійснення кривавих злочинів жінкою є скоєння великої кількості вбивств угорською графинею Ержебет Баторі (1560-1614 роки). Угорська графиня знаменита численними вбивствами молодих дівчат, також вона занесена до Книги рекордів Гіннесса за кількістю скоєних жінками вбивств. Приблизна кількість їі жертв становила 650 осіб. 3 історичних джерел відомо, що Баторі вела книгу жертв, яка під час слідства була знайдена. Баторі була впевнена, що кров незайманих омолоджує іiі шкіру і заради цього займалася катуванням дівчат. Жорстокість Ержебет у скоєнні серійних вбивств доведена показаннями понад 300 свідків, потерпілих та спотвореними тілами молодих дівчат.

Також у середині XVIII століття у Франції було здійснено низку злочинів щодо жінок Женев'євою де Сез. Необхідно звернутися до історії іiі життя, щоб розібратися в причинах скоєння нею злочинів. На півдні Франції Женев'єва де Сез проживала в маєтку зі своїм чоловіком - Франсуа де Сез. Женев'єва була покірною і слухняною дружиною, вела господарство. А Франсуа був товариським чоловіком і любив жіноче товариство, часто піддавався любовним романам. Після кожного роману 
Франсуа відбувався страшний випадок: невідома особа позбавляла життя подругу Франсуа. Із зазначеної причини з Парижа приїхали слідчі і встановили винного в скоєнні серії вбивств. Вбивцею виявилася Женев'єва, яка на суді зізналася у скоєнні нею злочинів через помсту з ревнощів. За протиправні діяння Женев' єву стратили публічно на площі.

3 початку XIX століття ставлення до жінки в суспільстві змінюється, жінки заявляють про соціальні, політичні, матеріальні права. Визнання повноцінності жіночої особистості, свободи іiі любові, жіночності сталося в усьому світі, жінку перестали вважати «річчю». Історики, говорячи про початок жіночої емансипації, вказують в основному економічні причини. Англійський історик Дж. М. Тревельян головну причину бачить у розвитку капіталістичних відносин, які вимагали робочих рук, і жінки разом з чоловіками починали працювати в полі і на фабриках. Відповідно, отримуючи заробітну плату, вони ставали економічно незалежними [5, с. 513].

3 точки зору історика М. Острогорського, Французька революція кінця XVIII століття привела до створення різних асоціацій, в які входили жінки. Вони були допущені до голосування в цих асоціаціях і навіть обіймали посади президентів [6, с. 177].

У 20-х роках XX ст. стали з'являтися дослідження, в яких робилася спроба не тільки піддати оцінці фізіологічні параметри жінки-злочинниці, але й вникнути у сферу їхнього світовідчуття і сприйняття навколишнього оточення. Підтримуючи погляди В. Томаса, М. Гернет стверджував, що причини жіночої злочинності не варто шукати в особливостях їхнього анатомічного устрою. Відповідно до соціологічного підходу причини скоєння злочинів жінками треба пояснювати умовами життя жінок. Їхнє життя менш цікаве і різнобічне, ніж у чоловіків, жінка більш прикута до сім’ї і менше бере участь у боротьбі за існування. Багато сфер праці залишалися для неї закритими. Звідси висновок, що М. Гернет убачав причини жіночої злочинності саме в соціальних умовах.

Проте повністю погодитися 3 вищеназваними авторами, які дотримувалися позиції, що причини жіночої злочинності криються лише в соціологічних умовах або в антропологічних особливостях, В. Внуков не міг. Автор стверджував, що в прояві себе зовні жінка під впливом певного соціального преса фізіологічніша за чоловіка. Іншими словами, у своїх реакціях вона ближча до їх фізіологічного коріння, ніж до їх психологічного налаштування. В. Внуков ствердно говорив, що «соціологія» жене жінку в «біологію». Звідси гострота і напруженість у їі злочинних діях [7, с. 211]. Звідси висновок, що В. Внуков пояснював причини жіночої злочинності не лише соціальними умовами, але й біологічними, автор поєднував ці категорії і вважав, що, лише діючи разом, вони можуть привести до скоєння жінкою насильницького злочину. На початку 70-х років минулого століття проблеми жіночої злочинності знову стали привертати до себе увагу дослідників. При цьому вивченню стали піддаватися не тільки статистичні закономірності й особливості особистості жінок-злочинниць, а й цілі видові прояви їхньої злочинної поведінки, а також особливості мікросоціального середовища, в тому числі і в місцях виконання покарання [8, с. 141-142].
Висновок. Таким чином, отримання жінками прав і свобод вплинуло на жіночу злочинність у цілому. Жіноча злочинність, як зазначено нами раніше, має глибокі історичні корені, на іiі розвиток і тенденції впливали насамперед підвалини в суспільстві і релігія. Вивчення жіночої злочинності і боротьба 3 нею неможливі без дослідження історичної генези жіночої злочинності. Адже у разі прийняття та введення нових методик боротьби з жіночою злочинністю необхідно враховувати походження жінки та їі статус у суспільстві.

\section{Лimepamypa:}

1. Ломброзо Ч. Женщина преступница и проститутка. Минск, $2000.574 \mathrm{c}$.

2. Пушкарева Н. Женщины Древней Руси. М.: Мысль, 1989. 288 с.

3. Яковлев А.М. Теория криминологии и социальная практика. М.: Наука, 1985. 247 с.

4. Каролина. Уголовно-судебное уложение Карла V. Алма-Ата, 1967. $152 \mathrm{c}$.

5. Тревельян Дж. М. История Англии от Чосера до королевы Виктории. Смоленск: Русич, 2001. 624 с.

6. Острогорский М.Я. Демократия и политические партии. М.: РОССПЭН, 1997. $243 \mathrm{c}$.

7. Внуков В.А. Женщины-убийцы. Убийства и убийцы. М.: Изд-во Мосздравотдела, 1928. С. 191-248.

8. Євдокімова М. Історичний аналіз жіночої злочинності. Підприємництво, господарство і право. 2018 . № 3. С. 140-142.

\section{Слюсарь Д. Ю. История женской преступности}

Аннотация. Статья посвящена исследованию истории женской преступности. Указывается, что сначала женщина рассматривалась исключительно как объект преступления. Доказано, что получение женщинами прав и свобод повлияло на женскую преступность в целом. Указывается, что женская преступность имеет глубокие исторические корни, ее развитие и тенденции развития, ее основы лежат в обществе и религии. Изучение женской преступности и борьба с ней невозможны без исследования исторического генезиса женской преступности. Ведь при принятии и введении новых методик борьбы с женской преступностью необходимо учитывать происхождение женщины и ее статус в обществе.

Ключевые слова: историческое развитие, причины преступности, женская преступность.

\section{Sliusar D. History of female criminality}

Summary. The article is devoted to the study of the history of female crime. It is noted that at first the woman was considered exclusively as the object of the crime. It has been proved that women's rights and freedoms have affected women's crime in general. It is pointed out that female crime, as we noted earlier, has deep historical roots, its development and tendencies were influenced, first of all, by the foundations in society and religion. Studying and combating female crime is impossible without the study of the historical genesis of female crime. After all, when adopting and introducing new methods of combating female crime, it is necessary to take into account the origin of the woman and her status in society.

Key words: historical development, causes of crime, female criminality. 